\title{
PEMANFAATAN PUPUK KANDANG AYAM, PUPUK KALIUM DAN MAGNESIUM TERHADAP PERTUMBUHAN JAGUNG MANIS (Zea mays saccharata Strut)
}

\author{
Riri Hartati Hutagalung \\ Alumnus Program Studi Agroteknologi, Fakultas Pertanian dan Peternakan, Universitas Tjut Nyak Dhien, \\ Medan 20123, Sumatera Utara, Indonesia. \\ Tengku Boumedine Hamid Zulkifli* \\ Program Studi Budidaya Perkebunan, Fakultas Pertanian dan Peternakan, Universitas Tjut Nyak Dhien, \\ Medan 20123, Sumatera Utara, Indonesia. Email: tengku_bobhz@yahoo.co.id \\ Irwan Agusnu Putra \\ Program Studi Agroteknologi, Fakultas Pertanian dan Peternakan, Universitas Tjut Nyak Dhien, Medan \\ 20123, Sumatera Utara, Indonesia. \\ Dedi Kurniawan \\ Program Studi Agroteknologi, Fakultas Pertanian dan Peternakan, Universitas Tjut Nyak Dhien, Medan \\ 20123, Sumatera Utara, Indonesia.
}

\begin{abstract}
Abstrak
Penelitian ini bertujuan untuk mengkaji pemanfaatan pupuk kandang ayam dan pemberian pupuk kalium serta magnesium terhadap pertumbuhan jagung manis (Zea mays saccharata Sturt). Metode yang digunakan dalam penelitian ini adalah rancangan acak kelompok (RAK) Faktorial dengan tiga faktor. Faktor pertama yaitu pupuk kandang ayam (A) terdiri dari: $\mathrm{A}_{0}=$ tanpa pupuk kandang ayam, $\mathrm{A}_{1}=10 \mathrm{ton} / \mathrm{ha}(100 \mathrm{~g} / \mathrm{polybag})$. Faktor kedua yaitu pupuk magnesium (D) terdiri dari: $\mathrm{D}_{0}=0 \mathrm{~g} /$ polybag, $\mathrm{D}_{1}=17 \mathrm{~g} /$ polybag. Faktor ketiga yaitu pupuk kalium $(\mathrm{K})$, terdiri dari: $\mathrm{K}_{0}=0 \mathrm{KCl} / \mathrm{ha}, \mathrm{K}_{1}=$ $0,83 \mathrm{~g} /$ polybag, $\mathrm{K}_{2}=1,66 \mathrm{~g} /$ polybag, $\mathrm{K}_{3}=2,50 \mathrm{~g} / \mathrm{polybag}$. Hasil penelitian menunjukkan bahwa pemberian pupuk kandang ayam signifikan meningkatkan tinggi tanaman 4 dan 6 MST, bobot kering tajuk dan akar, bobot kering total, kandungan $\mathrm{K}$ dan $\mathrm{Mg}$ di daun, serapan hara $\mathrm{K}$ dan $\mathrm{Mg}$ pada tanaman jagung manis. Pemberian pupuk Mg (dolomit) signifikan meningkatkan bobot kering tajuk dan akar, bobot kering total, dan kandungan $\mathrm{Mg}$ di daun tanaman jagung manis. Interaksi pupuk kandang ayam dengan pupuk $\mathrm{Mg}$ berpengaruh tidak nyata terhadap semua parameter penelitian ini. Pemberian pupuk $\mathrm{K}(\mathrm{KCl})$ signifikan meningkatkan bobot kering tajuk, bobot kering total, dan kandungan $\mathrm{K}$ di daun tanaman jagung manis. Interaksi pupuk kandang ayam dengan pupuk $\mathrm{K}$ hanya berpengaruh nyata terhadap tinggi tanaman 2 MST. Interaksi pupuk Mg dengan $\mathrm{K}$ signifikan meningkatkan bobot kering tajuk dan bobot kering total tanaman jagung manis. Interaksi pupuk kandang ayam, pupuk $\mathrm{Mg}$ dan $\mathrm{K}$ signifikan meningkatkan bobot kering akar tertinggi pada interaksi $\mathrm{A}_{1} \mathrm{D}_{0} \mathrm{~K}_{1}$ (pupuk kandang ayam $100 \mathrm{~g} /$ polybag + tanpa pupuk $\mathrm{Mg}+$ pupuk $\mathrm{K} 083 \mathrm{~g} / \mathrm{polybag}$ ) sebesar $20,93 \mathrm{~g}$.
\end{abstract}

Kata Kunci: jagung, kalium, magnesium, pupuk kandang ayam

\section{PENDAHULUAN}

Berdasarkan data BPS produksi jagung di Provinsi Sumatera Utara tahun 2013 sekitar 5,587 ton/ha, tahun 2014 sekitar 5,782 ton/ha, dan tahun 2015 sekitar 6,233 ton/ha (BPS, 2016). Jumlah produksi ini semakin meningkat tetapi belum mencukupi kebutuhan jagung.

Tanaman Jagung manis termasuk bahan pangan penting karena merupakan sumber karbohidrat kedua setelah beras. Jagung tidak hanya sebagai bahan pangan, namun dapat juga dijadikan sebagai bahan pakan ternak dan industri sehingga penanaman jagung perlu dilakukan untuk memenuhi kebutuhan tersebut. Menurut Iskandar, (2003) jagung manis memiliki kandungan vitamin dan mineral disetiap $100 \mathrm{~g}$ biji diantaranya 96 kalori energi, 3,5 g protein, 1,0 g lemak, 22,8 g karbohidrat, 3,0 mg kalsium, 111,0 mg fosfor, 0,7 mg besi, $400 \mathrm{Si}$ vitamin A, 0,15 mg Vitamin B, $12 \mathrm{mg}$ Vitamin $\mathrm{C}$, dan 72,7 g air.
Hara makro Magnesium (Mg) merupakan unsur hara esensial yang sangat dibutuhkan tanaman dalam pembentukan hijau daun (chlorofil) dan sebagai co-faktor hampir pada seluruh enzim dalam proses metabolisme tanaman seperti proses fotosintesa, pembentukan sel, pembentukan protein, pembentukan pati, transfer energi serta mengatur pembagian dan distribusi karbohidrat keseluruh jaringan tanaman.

Lahan pertanian di Sumatera sendiri pada umumnya memiliki reaksi tanah masam sampai agak masam ( $\mathrm{pH}$ 4,6-5,5) serta kandungan liat yang cukup tinggi dan kadar kalium relatif rendah berkisar 0,1-0,2 me/100 gr tanah serta kompleks adsorbsi didominasi oleh Ca dan Mg (Puslitanak, 2000).

Menurut Damanik et al., (2011) untuk mengatasi masalah tersebut diatas, perlu dilakukan penambahan unsur kalsium dan magnesium melalui pemupukan dolomit $\mathrm{CaMg}\left(\mathrm{CO}_{3}\right)_{2}$ yang merupakan bahan kapur yang umum diberikan. Namun pada umumnya yang dilakukan 
petani saat pengolahan tanah ialah petani memberikan kapur dolomit secara tidak terkontrol dan sembarangan tanpa mengetahui dosis yang tepat.

Kalium mempunyai pengaruh sebagai penyeimbang keadaan bila tanaman kelebihah N. Unsur ini meningkatkan sintesis dan translokasi karbohidrat, sehingga meningkatkan ketebalan dinding sel dan kekuatan batang. Kalium juga dapat meningkatkan kandungan gula (Forth, 1978).

Untuk mendukung ketersediaan hara kalium tanah, perlu upaya perlakuan untuk mendukung ketersediaannya melalui pemanfaatan pupuk kandang ayam dan pemberian pupuk kalium serta magnesium terhadap pertumbuhan jagung manis (Zea mays saccharata Sturt).

\section{METODE}

\section{Tempat dan Waktu Penelitian}

Penelitian ini dilaksanakan di lahan pertanian Universitas Islam Sumatera Utara. Pelaksanaan penelitian dimulai pada Juni sampai September 2016.

\section{Bahan dan Alat}

Bahan yang digunakan dalam penelitian ini adalah benih jagung manis, pupuk kandang ayam, kapur dolomit sebagai sumber dari pupuk magnesium (Mg), pupuk $\mathrm{KCl}$ dan bahan-bahan lain yang mendukung penelitian ini. Alat-alat yang digunakan adalah cangkul, gembor, polibeg, label nama, alat tulis, plastik, ember, meteran dan lain-lain.

\section{Model Rancangan}

Penelitian dilakukan dengan menggunakan Rancangan Acak Kelompok (RAK) faktorial terdiri dari tiga faktor yaitu faktor pertama : pupuk kandang ayam, yakni: $\mathrm{A} 0=$ tanpa pupuk kandang ayam, $\mathrm{A}_{1}=$ pupuk kandang ayam 10 ton/ha (100 g/polybag), faktor kedua: kapur dolomit $(\mathrm{Mg})$, yakni : $\mathrm{D}_{0}=$ tanpa dolomit $(\mathrm{Mg}), \mathrm{D}_{1}=$ kapur dolomit (Mg) $17 \mathrm{~g} /$ polybag dan faktor ketiga yaitu pupuk kalium terdiri dari $\mathrm{K}_{0}=$ tanpa pupuk kalium, $\mathrm{K}_{1}=$ $50 \mathrm{~kg} \mathrm{~K} 2 \mathrm{O} / \mathrm{ha}\left(83 \mathrm{~kg} \mathrm{KCl} / \mathrm{ha}=0,83 \mathrm{~g} /\right.$ polybag), $\mathrm{K}_{2}=100$ $\mathrm{kg} \mathrm{K} \mathrm{K}_{2} \mathrm{O} / \mathrm{ha}(167 \mathrm{~kg} \mathrm{KCl} / \mathrm{ha}=1,67 \mathrm{~g} /$ polybag$), \mathrm{K}_{3}=150$ $\mathrm{kg} \mathrm{K} 2 \mathrm{O} / \mathrm{ha}(250 \mathrm{~kg} \mathrm{KCl} / \mathrm{ha}=2,50 \mathrm{~g} /$ polybag$)$.

\section{Persiapan Tempat Penelitian}

Di awali dengan pembuatan Baris polibag pada masing-masing ulangan dengan berat tanah 20 $\mathrm{kg} /$ polybag. Tempat penelitian diatur sedemikian rupa sesuai dengan perlakuan. Setiap percobaan dalam satu ulangan diberi jarak selebar $50 \mathrm{~cm}$, sedangkan jarak antar blok percobaan selebar $100 \mathrm{~cm}$.

\section{Persiapan Pupuk Dasar}

Aplikasi pupuk kandang ayam \& kapur dolomit $(\mathrm{Mg})$, diinkubasi pada polibeg perlakuan dan dibiarkan selama 2 minggu. Aplikasi pupuk perlakuan $(\mathrm{KCl})$ pada setiap polibeg perlakuan dengan dosis perlakuan. Setelah selesai masa inkubasi pupuk kandang dan aplikasi kapur dolomit $(\mathrm{Mg})$ dan $(\mathrm{KCl})$, lalu dimulai penanaman bibit jagung manis.

\section{Penanaman}

Membuat lubang tanam dengan tugal di polibeg, kedalaman tanah $3 \mathrm{~cm}$. Selanjutnya lubang diberi benih sesuai perlakuan yaitu 1 benih/lubang kemudian ditutup dengan sedikit tanah yang gembur.

\section{Pemupukan}

Aplikasi pupuk kandang ayam dan kapur dolomite $(\mathrm{Mg})$, diinkubasi pada polybag perlakuan dan dibiarkan selama 2 minggu. Pemberian pupuk dasar untuk jagung manis yaitu: urea $=435 \mathrm{~kg} / \mathrm{ha}, \mathrm{TSP}=335 \mathrm{~kg} / \mathrm{ha}$, SP-36 = $428 \mathrm{~kg} / \mathrm{ha}$, dan $\mathrm{KCl} 250 \mathrm{~kg} / \mathrm{ha}$ (Palungkun \& Budiarti, 2004). Setelah dikonversikan menjadi yaitu urea= 4,35 g/polybag, TSP= 3,35 g/polybag, $\mathrm{SP}-36=4,28 \mathrm{~g} / \mathrm{ha}$ dan $\mathrm{KCl}=2,5 \mathrm{~g} / \mathrm{ha}$.

Pemberian pupuk urea dilakukan yaitu sebanyak 2/3 urea diberikan diawal penanaman dan 1/3 sisanya diberikan pada 30 HST, TSP diberikan pada awal penanaman. Aplikasi pupuk perlakuan $(\mathrm{KCl})$ pada setiap polibeg perlakuan dengan dosis perlakuan. Setelah selesai masa inkubasi pupuk kandang dan aplikasi kapur dolomit dan perlakuan $(\mathrm{KCl})$, lalu dimulai penanaman bibit jagung manis.

\section{Pemberian Kapur}

Pemberian kapur (dolomit) untuk perlakuan berdasarkan hasil analisa Al-dd tanah. Menurut Sanchez (1976) dalam Hardjowigeno, (2007) dengan menggunakan kapur 1,5 Al-dd (t/ha) dapat menetralkan 85-90\% Al-dd dalam tanah yang mengandung $2-7 \%$ bahan organik.

\section{Pemeliharaan dan Pengendalian Hama Penyakit}

Penyiangan dan penyulaman dilakukan sebelum tanaman berumur 15 hari setelah tanam baik secara manual atau kimiawi dengan menggunakan herbisida Smart 480 AS dengan dosis 1 l/ha. Penyiraman dilakukan 2 kali sehari pada pagi dan sore hari pada keadaan kering (tidak turun hujan). Pembumbunan dilakukan pada saat tanaman berumur 15 hari dan pembumbunan kedua dilakukan setelah tanaman berumur 40 hari. Pengendalian hama dan penyakit dilakukan dengan pencegahan. Untuk pengendalian hama diberikan decis 2,5 EC dengan dosis 2 $\mathrm{ml} / \mathrm{l}$ air.

\section{Panen dan Parameter}

Panen tanaman jagung manis dilakukan sekitar umur vegetatif yaitu 45 hari setelah tanam (HST), dimana pada saat tersebut pertumbuhan daun tanaman telah maksimal dengan ditandai mulai akan keluarnya bunga.

Pengamatan tinggi tanaman $(\mathrm{cm})$ dilakukan dari pangkal tumbuh tanaman pada permukaan tanah yang sudah ditandai dengan menggunakan patok standart sampai pada ujung daun tertinggi. Pengukuran dimulai pada saat tanaman berumur 2, 4, dan 6 MST.

Daun yang diamati adalah daun bagian tengah, kemudian diukur dengan menggunakan meteran. Luas daun dihitung dengan menggunakan rumus: $\mathrm{p}$ x $1 \mathrm{x} \mathrm{k}$. Konstanta jagung manis yaitu 0,75 (Agus, 2012). Pengamatan dilakukan pada saat tanaman berumur 2, 4, dan 6 MST.

Bobot kering tajuk dan akar tanaman jagung manis diukur pada saat panen vegetatif dengan cara 
memotong bagian akar dan tajuk kemudian dikeringovenkan di suhu $70^{\circ} \mathrm{C}$ selama 24 jam atau pada kadaan bobot stabil. Setelah bobot stabil lalu ditimbang. Bobot kering tanaman diukur pada saat panen yaitu akar dan daun (tajuk), lalu dikering oven dalam keadaan suhu $70^{\circ} \mathrm{C}$ selama 24 jam atau pada keadaan bobot stabil. Setelah bobot stabil lalu ditimbang.

Daun diambil untuk analisa kandungan kalium dan magnesium dilakukan pada saat tanaman berumur 30 hari setelah tanam dan daun yang ambil untuk sampel adalah daun ke 5, 6 dan 7. Lalu daun diekstrak dan di analisa di laboratorium.

Analisis serapan hara tanaman $(\mathrm{K}$ dan $\mathrm{Mg})$ yaitu menghitung perkalian kandungan hara pada daun dengan bobot kering brangkasan (tanaman) untuk mengetahui potensi serapan hara daun. Untuk mendapatkan nilai serapan hara tanaman dihitung dengan menggunakan rumus:
Serapan hara $\mathrm{K}=$ nilai hara daun $\mathrm{x}$ bobot kering tanaman Serapan hara $\mathrm{Mg}=$ nilai hara daun $\mathrm{x}$ bobot kering tanaman

\section{HASIL DAN PEMBAHASAN Hasil Uji F}

Rekapitulasi hasil uji $\mathrm{F}$ semua parameter pada penelitian ini dapat dilihat pada Tabel 1. Diperoleh bahwa pemberian pupuk kandang ayam signifikan meningkatkan tinggi tanaman 4 dan 6 MST, bobot kering tajuk dan akar, bobot kering total, kandungan $\mathrm{K}$ dan $\mathrm{Mg}$ di daun, serapan hara $\mathrm{K}$ dan $\mathrm{Mg}$ pada tanaman jagung manis. Pemberian pupuk Mg (dolomit) signifikan meningkatkan bobot kering tajuk dan akar, bobot kering total, dan kandungan $\mathrm{Mg}$ di daun tanaman jagung manis. Interaksi pupuk kandang ayam dengan pupuk $\mathrm{Mg}$ berpengaruh tidak nyata terhadap semua parameter penelitian ini.

Tabel 1. Rekapitulasi uji $\mathrm{F}$ dari pengaruh pupuk kandang ayam, pupuk magnesium, dan kalium, serta interaksinya terhadap semua parameter tanaman jagung manis.

\begin{tabular}{|c|c|c|c|c|c|c|c|c|}
\hline \multirow{3}{*}{$\begin{array}{c}\text { Sumber } \\
\text { Keragaman }\end{array}$} & \multicolumn{8}{|c|}{ F-hitung } \\
\hline & \multicolumn{3}{|c|}{ Tinggi Tanaman $(\mathrm{cm})$} & \multicolumn{3}{|c|}{ Luas Daun $\left(\mathrm{cm}^{2}\right)$} & \multirow{2}{*}{$\begin{array}{c}\text { Bobot Kering } \\
\text { Tajuk (g) }\end{array}$} & \multirow{2}{*}{$\begin{array}{c}\text { Bobot Kering } \\
\text { Akar }(\mathrm{g})\end{array}$} \\
\hline & $2 \mathrm{MST}$ & $4 \mathrm{MST}$ & $6 \mathrm{MST}$ & $2 \mathrm{MST}$ & $4 \mathrm{MST}$ & $6 \mathrm{MST}$ & & \\
\hline Ulangan & $0,59 \mathrm{tn}$ & $4,05 *$ & 1,46 tn & $0,93 \mathrm{tn}$ & $8,26 *$ & $0,40 \mathrm{tn}$ & $4,82 *$ & $2,69 \mathrm{tn}$ \\
\hline Pukan Ayam (A) & $1,58 \mathrm{tn}$ & $7,11 *$ & $6,36 *$ & $0,20 \mathrm{tn}$ & 2,96 tn & 2,14 tn & $20,12 *$ & $14,00 *$ \\
\hline Dolomit (D) & $1,27 \mathrm{tn}$ & 1,42 tn & $1,04 \mathrm{tn}$ & $0,32 \mathrm{tn}$ & $3,50 \mathrm{tn}$ & 0,47 tn & $10,11 *$ & $4,34 *$ \\
\hline$A \times D$ & $2,43 \mathrm{tn}$ & 0,10 th & $0,01 \mathrm{tn}$ & $4,13 \mathrm{tn}$ & 0,14 th & 0,27 tn & $0,34 \mathrm{tn}$ & $1,44 \mathrm{tn}$ \\
\hline Pupuk Kalium (K) & $0,20 \mathrm{tn}$ & $0,49 \mathrm{tn}$ & 0,40 tn & $0,22 \mathrm{tn}$ & $1,61 \mathrm{tn}$ & $1,59 \mathrm{tn}$ & $3,87 *$ & $1,24 \mathrm{tn}$ \\
\hline$A \times K$ & $3,35 *$ & 0,42 tn & $0,80 \mathrm{tn}$ & $2,43 \mathrm{tn}$ & $0,80 \mathrm{th}$ & 1,47 tn & $2,05 \mathrm{tn}$ & $2,00 \mathrm{tn}$ \\
\hline $\mathrm{D} \times \mathrm{K}$ & $1,51 \mathrm{tn}$ & 0,12 tn & 0,18 th & $0,88 \mathrm{tn}$ & 1,14 tn & 0,45 tn & $3,83 *$ & $2,68 \mathrm{tn}$ \\
\hline $\mathrm{A} \times \mathrm{D} \times \mathrm{K}$ & $1,75 \mathrm{tn}$ & 2,39 tn & 0,96 tn & $1,11 \mathrm{tn}$ & 1,33 th & $0,78 \mathrm{tn}$ & $0,75 \mathrm{tn}$ & $3,10 *$ \\
\hline KK (\%) & 16,27 & 15,90 & 13,69 & 19,57 & 27,18 & 26,91 & $23,55 \%$ & 25,78 \\
\hline
\end{tabular}

Lanjutan Tabel 1. Rekapitulasi uji F dari pengaruh pupuk kandang ayam, pupuk magnesium, dan kalium, serta interaksinya terhadap semua parameter tanaman jagung manis

\begin{tabular}{|c|c|c|c|c|c|}
\hline \multirow[b]{2}{*}{ Sumber Keragaman } & \multicolumn{5}{|c|}{ F-hitung } \\
\hline & $\begin{array}{l}\text { Bobot Kering } \\
\text { Total }(\mathrm{g})\end{array}$ & $\begin{array}{c}\text { Kandungan } \mathrm{K} \\
\text { di daun }(\%)\end{array}$ & $\begin{array}{c}\text { Kandungan } \mathrm{Mg} \\
\text { di daun }(\%)\end{array}$ & $\begin{array}{c}\text { Serapan Hara } \\
\text { K }(\%)\end{array}$ & $\begin{array}{c}\text { Serapan Hara } \\
\operatorname{Mg}(\%)\end{array}$ \\
\hline Ulangan & $4,05 *$ & 1,49 tn & $0,01 \mathrm{tn}$ & 1,46 tn & 0,70 tn \\
\hline Pukan Ayam (A) & $22,68 *$ & $17,23 *$ & $5,41 *$ & $10,59 *$ & $11,26 *$ \\
\hline Dolomit (D) & $10,47 *$ & 3,39 tn & $5,18 *$ & $1,05 \mathrm{tn}$ & 0,12 tn \\
\hline$A \times D$ & 0,63 th & 0,14 th & $2,33 \mathrm{tn}$ & $0,07 \mathrm{tn}$ & 0,18 th \\
\hline Pupuk Kalium (K) & $3,61 *$ & $5,04 *$ & $1,64 \mathrm{tn}$ & $1,53 \mathrm{tn}$ & 1,95 tn \\
\hline $\mathrm{A} \times \mathrm{K}$ & $2,25 \mathrm{tn}$ & $1,11 \mathrm{tn}$ & $0,23 \mathrm{tn}$ & $0,73 \mathrm{tn}$ & $0,91 \mathrm{tn}$ \\
\hline $\mathrm{D} \times \mathrm{K}$ & $3,65 *$ & 0,46 tn & $0,46 \mathrm{tn}$ & $1,03 \mathrm{tn}$ & $1,35 \mathrm{tn}$ \\
\hline $\mathrm{A} \times \mathrm{D} \times \mathrm{K}$ & 0,46 th & 3,16 th & 0,13 th & 0,59 th & 0,08 tn \\
\hline $\mathrm{KK}(\%)$ & 21,78 & 10,95 & 20,03 & 39,82 & 38,04 \\
\hline
\end{tabular}

Keterangan: tanda *menunjukkan perlakuan berpengaruh nyata pada uji $\mathrm{F}$ taraf $5 \%$ dan tanda tn menunjukkan berpengaruh tidak nyata.

Pemberian pupuk $\mathrm{K} \quad(\mathrm{KCl})$ signifikan meningkatkan bobot kering tajuk, bobot kering total, dan kandungan $\mathrm{K}$ di daun tanaman jagung manis. Interaksi pupuk kandang ayam dengan pupuk $\mathrm{K}$ hanya berpengaruh nyata terhadap tinggi tanaman 2 MST. Interaksi pupuk $\mathrm{Mg}$ dengan $\mathrm{K}$ signifikan meningkatkan bobot kering tajuk dan bobot kering total tanaman jagung manis. Interaksi pupuk kandang ayam, pupuk Mg dan $\mathrm{K}$ signifikan meningkatkan bobot kering akar tanaman jagung manis.

\section{Interaksi Pupuk Kandang Ayam dengan Dolomit (AxD) Tinggi Tanaman (cm)}

Hasil analisis pengamatan dan analisis sidik ragam dapat dilihat tinggi tanaman jagung manis pada interaksi pupuk kandang ayam dengan pupuk magnesium pada umur 2, 4, dan 6 MST dapat dilihat pada Tabel 2.

Tinggi tanaman pada umur 2 MST dengan rataan tertinggi pada A1D1 yaitu $28,39 \mathrm{~cm}$. Pengamatan tinggi tanaman umur 4 MST dengan rataan tertinggi pada A1D0 
yaitu 80,39 $\mathrm{cm}$. Pengamatan tinggi tanaman umur $6 \mathrm{MST}$ dengan rataaan tertinggi pada A1D0 yaitu $155,95 \mathrm{~cm}$.

Tabel 2. Tinggi tanaman jagung manis pada interaksi pupuk kandang ayam dengan pupuk magnesium pada umur 2, 4, dan 6 MST

\begin{tabular}{cccc}
\hline Perlakuan & $\mathrm{D}_{0}$ & $\mathrm{D}_{1}$ & Rataan \\
\hline \multicolumn{4}{c}{ Tinggi Tanaman 2 MST } \\
$\mathrm{A}_{0}$ & 28,22 & 24,78 & 26,50 \\
$\mathrm{~A}_{1}$ & 27,83 & 28,39 & 28,11 \\
\hline Rataan & 28,03 & 26,58 \\
\hline \multicolumn{5}{c}{ Tinggi Tanaman 4 MST } \\
$\mathrm{A}_{0}$ & 72,36 & 67,22 & $69,79 \mathrm{~b}$ \\
$\mathrm{~A}_{1}$ & 80,39 & 77,39 & $78,89 \mathrm{a}$ \\
\hline Rataan & 76,38 & 72,31 \\
\hline \multicolumn{5}{c}{ Tinggi Tanaman 6 MST } \\
$\mathrm{A}_{0}$ & 142,03 & 135,67 & $138,85 \mathrm{~b}$ \\
$\mathrm{~A}_{1}$ & 155,95 & 150,64 & $153,29 \mathrm{a}$ \\
\hline Rataan & 148,99 & 143,15
\end{tabular}

Keterangan: angka yang diikuti oleh huruf yang sama pada baris dan kolom yang sama menujukkan berbeda tidak nyata pada BNJ taraf $5 \%$.

\section{Luas Daun $\left(\mathbf{c m}^{2}\right)$}

Hasil analisis pengamatan dan analisis sidik ragam dapat dilihat bahwa luas daun tanaman jagung manis pada interaksi pupuk kandang ayam dan pupuk magnesium di umur 2, 4, dan 6 MST dapat dilihat pada Tabel 3.

Tabel 3. Luas daun tanaman jagung manis pada interaksi pupuk kandang ayam dengan pupuk magnesium pada umur 2, 4, dan 6 MST

\begin{tabular}{ccrc}
\hline Perlakuan & \multicolumn{1}{c}{$\mathrm{D}_{0}$} & $\mathrm{D}_{1}$ & Rataan \\
\hline \multicolumn{4}{c}{ Luas Daun 2 MST } \\
$\mathrm{A}_{0}$ & 33,00 & 28,44 & 30,72 \\
$\mathrm{~A}_{1}$ & 30,21 & 32,79 & 31,50 \\
\hline Rataan & 31,60 & 30,61 \\
\hline \multicolumn{4}{c}{ Luas Daun 4 MST } \\
$\mathrm{A}_{0}$ & 183,65 & 161,90 & 172,77 \\
$\mathrm{~A}_{1}$ & 214,10 & 181,44 & 197,77 \\
\hline Rataan & 198,88 & 171,67 \\
\hline \multicolumn{5}{c}{ Luas Daun 4 MST } \\
$\mathrm{A}_{0}$ & 411,15 & 405,54 & 408,34 \\
$\mathrm{~A}_{1}$ & 477,96 & 437,23 & 457,59 \\
\hline Rataan & 444,55 & 421,39 \\
\hline
\end{tabular}

Keterangan: angka yang diikuti oleh huruf yang sama pada baris dan kolom yang sama menujukkan berbeda tidak nyata pada $\mathrm{BNJ}$ taraf $5 \%$

Pada Tabel 3 pengamatan pada luas daun umur 2 MST dengan rataan tertinggi pada A0D0 yaitu 33,00 $\mathrm{cm}^{2}$. Pengamatan luas daun umur 4 MST dengan rataan tertinggi pada A1D0 yaitu $214,10 \mathrm{~cm}^{2}$. Pengamatan luas daun umur 6 MST dengan rataaan tertinggi pada A1D0 yaitu $477,96 \mathrm{~cm}^{2}$.

\section{Bobot Kering (Tajuk, Akar, dan Total)}

Hasil analisis pengamatan dan analisis sidik ragam dapat dilihat bahwa bobot kering tajuk, akar, dan total tanaman jagung manis pada interaksi pupuk kandang ayam dan pupuk magnesium dapat dilihat pada Tabel 4.
Tabel 4. Bobot kering tajuk dan akar tanaman jagung manis pada interaksi pupuk kandang ayam dengan pupuk magnesium

\begin{tabular}{|c|c|c|c|}
\hline Perlakuan & $\mathrm{D}_{0}$ & $\overline{D_{1}}$ & Rataan \\
\hline \multicolumn{4}{|c|}{ Bobot Kering Tajuk (g) } \\
\hline $\mathrm{A}_{0}$ & 55,25 & 40,76 & $48,01 \mathrm{~b}$ \\
\hline $\mathrm{A}_{1}$ & 70,28 & 60,28 & $65,28 \mathrm{a}$ \\
\hline Rataan & $62,77 \mathrm{a}$ & $50,52 \mathrm{~b}$ & \\
\hline \multicolumn{4}{|c|}{ Bobot Kering Akar (g) } \\
\hline $\mathrm{A}_{0}$ & 14,71 & 11,05 & $12,88 \mathrm{~b}$ \\
\hline $\mathrm{A}_{1}$ & 17,54 & 16,56 & $17,05 \mathrm{a}$ \\
\hline Rataan & $16,13 \mathrm{a}$ & $13,81 \mathrm{~b}$ & \\
\hline \multicolumn{4}{|c|}{ Bobot Kering Total $(\mathrm{g})$} \\
\hline $\mathrm{A}_{0}$ & 69,97 & 51,82 & $60,89 \mathrm{~b}$ \\
\hline $\mathrm{A}_{1}$ & 87,82 & 76,84 & $82,33 \mathrm{a}$ \\
\hline Rataan & $78,89 \mathrm{a}$ & $64,33 \mathrm{~b}$ & \\
\hline
\end{tabular}

Keterangan: angka yang diikuti oleh huruf yang sama pada baris dan kolom yang sama menujukkan berbeda tidak nyata pada $\mathrm{BNJ}$ taraf $5 \%$

Tabel 4 dapat dilihat bahwa pemberian pupuk kandang ayam dan pupuk magnesium berpengaruh nyata terhadap bobot kering tajuk, bobot kering akar, dan bobot kering total tanaman jagung manis. Interaksi perlakuan pupuk kandang ayam dan dolomit pada bobot kering tajuk tanaman jagung manis terlihat pada rataan perlakuan A1D0 dengan nilai tertinggi 70,28 g. Interaksi perlakuan pupuk kandang ayam dan dolomit pada bobot kering akar tanaman jagung manis terlihat pada rataan perlakuan A1D0 dengan nilai tertinggi 17,54 g. Interaksi perlakuan pupuk kandang ayam dan dolomit pada bobot kering tanaman jagung manis terlihat pada rataan perlakuan A1D0 dengan nilai tertinggi 87,82 g.

\section{Kandungan K dan Mg pada Daun}

Hasil analisis pengamatan dan analisis sidik ragam dapat dilihat bahwa kandungan $\mathrm{K}$ dan $\mathrm{Mg}$ di daun tanaman jagung manis pada interaksi pupuk kandang ayam dan pupuk magnesium dapat dilihat pada Tabel 5 .

Tabel 5. Kandungan $\mathrm{K}$ dan $\mathrm{Mg}$ di daun tanaman jagung manis pada interaksi pupuk kandang ayam dengan pupuk magnesium

\begin{tabular}{cccc}
\hline Perlakuan & $\mathrm{D}_{0}$ & $\mathrm{D}_{1}$ & Rataan \\
\hline \multicolumn{4}{c}{ Kandungan $\mathrm{K}(\%)$} \\
$\mathrm{A}_{0}$ & 1,30 & 1,38 & $1,34 \mathrm{~b}$ \\
$\mathrm{~A}_{1}$ & 1,51 & 1,63 & $1,57 \mathrm{a}$ \\
\hline Rataan & 1,40 & 1,51 \\
\hline \multicolumn{4}{c}{ Kandungan $\mathrm{Mg}(\%)$} \\
$\mathrm{A}_{0}$ & 0,28 & 0,37 & $0,32 \mathrm{~b}$ \\
$\mathrm{~A}_{1}$ & 0,37 & 0,39 & $0,38 \mathrm{a}$ \\
\hline Rataan & $0,32 \mathrm{~b}$ & $0,38 \mathrm{a}$ \\
\hline
\end{tabular}

Keterangan: angka yang diikuti oleh huruf yang sama pada baris dan kolom yang sama menujukkan berbeda tidak nyata pada BNJ taraf 5\%

Tabel 5 dapat dilihat bahwa pemberian pupuk kandang ayam berpengaruh nyata terhadap kandungan $\mathrm{K}$ dan $\mathrm{Mg}$ di daun tanaman jagung manis. Pemberian pupuk magnesium berpengaruh nyata terhadap kandungan $\mathrm{Mg}$ di daun tanaman jagung manis. Interaksi perlakuan pupuk kandang ayam dan perlakuan dolomit terhadapkandungan 
kalium pada daun jagung manis terlihat pada rataan perlakuan A1D1 dengan nilai tertinggi 1,63\%. interaksi perlakuan pupuk kandang ayam dan perlakuan dolomit terhadap kandungan magnesium pada daun jagung manis terlihat pada rataan perlakuan A1D1 dengan nilai tertinggi $0,39 \%$.

\section{Serapan Hara K dan Mg}

Hasil analisis pengamatan dan analisis sidik ragam dapat dilihat bahwa serapan hara $\mathrm{K}$ dan $\mathrm{Mg}$ tanaman jagung manis pada interaksi pupuk kandang ayam dan pupuk magnesium dapat dilihat pada Tabel 6 .

Tabel 6. Serapan hara $\mathrm{K}$ dan $\mathrm{Mg}$ tanaman jagung manis pada interaksi pupuk kandang ayam dengan pupuk magnesium

\begin{tabular}{clcc}
\hline Perlakuan & \multicolumn{1}{c}{$\mathrm{D}_{0}$} & $\mathrm{D}_{1}$ & Rataan \\
\hline \multicolumn{4}{c}{ Serapan Hara K $(\%)$} \\
$\mathrm{A}_{0}$ & 0,88 & 0,69 & $0,78 \mathrm{~b}$ \\
$\mathrm{~A}_{1}$ & 1,30 & 1,19 & $1,25 \mathrm{a}$ \\
\hline Rataan & 1,09 & 0,94 \\
\hline \multicolumn{5}{c}{ Serapan Hara $\mathrm{Mg}(\%)$} \\
$\mathrm{A}_{0}$ & 0,19 & 0,19 & $0,19 \mathrm{~b}$ \\
$\mathrm{~A}_{1}$ & 0,31 & 0,29 & $0,30 \mathrm{a}$ \\
\hline Rataan & 0,25 & 0,24 \\
\hline
\end{tabular}

Keterangan: angka yang diikuti oleh huruf yang sama pada baris dan kolom yang sama menujukkan berbeda tidak nyata pada BNJ taraf 5\%

Tabel 6 dapat dilihat bahwa pemberian pupuk kandang ayam berpengaruh nyata terhadap serapan hara $\mathrm{K}$ dan Mg pada tanaman jagung manis, namun pemberian pupuk magnesium berpengaruh tidak nyata. Interaksi perlakuan pupuk kandang ayam dan perlakuan dolomit terhadap serapan hara kalium tanaman jagung manis terlihat pada rataan A1D0 dengan nilai tertinggi 1,30\%. Interaksi perlakuan pupuk kandang ayam dan perlakuan dolomit terhadap serapan hara magnesium tanaman jagung manis terlihat pada rataan A1D0 dengan nilai tertinggi $0,31 \%$.

\section{Interaksi Pupuk Kandang Ayam dengan Pupuk Kalium (AxK) Tinggi Tanaman $(\mathrm{cm})$}

Hasil analisis pengamatan dan analisis sidik ragam dapat dilihat tinggi tanaman jagung manis pada interaksi pupuk kandang ayam dengan pupuk kalium pada umur 2, 4, dan 6 MST dapat dilihat pada Tabel 7.

Pemberian pupuk kandang (A) berpengaruh tidak nyata pada pengamatan umur 2 MST dan memberikan hasil yang nyata pada pengamatan umur 4 dan 6 MST. Pemberian pupuk kalium (K) berpengaruh tidak nyata pada tinggi tanaman umur 2, 4, dan 6 MST. Interaksi perlakuan pupuk kandang ayam dan pemberian pupuk kalium berpengaruh nyata terhadap tinggi tanaman umur 2 MST, dan berpengaruh tidak nyata pada tinggi tanaman umur 4 MST dan 6 MST.

Pada Tabel 7 pengamatan pada tinggi tanaman umur $2 \mathrm{MST}$ dengan rataan tertinggi pada $\mathrm{A}_{1} \mathrm{~K}_{0}$ yaitu $30,06 \mathrm{~cm}$. Pengamatan tinggi tanaman umur $4 \mathrm{MST}$ dengan rataan tertinggi pada $\mathrm{A}_{1} \mathrm{~K}_{0}$ yaitu $83,39 \mathrm{~cm}$. Pengamatan tinggi tanaman umur 6 MST dengan rataaan tertinggi pada $\mathrm{A}_{1} \mathrm{~K}_{0}$ yaitu $164,56 \mathrm{~cm}$.
Tabel 7. Tinggi tanaman jagung manis pada interaksi pupuk kandang ayam dengan pupuk kalium pada umur 2, 4, dan $6 \mathrm{MST}$

\begin{tabular}{cccccc}
\hline Perlakuan & $\mathrm{K}_{0}$ & $\mathrm{~K}_{1}$ & $\mathrm{~K}_{2}$ & $\mathrm{~K}_{3}$ & Rataan \\
\hline \multicolumn{5}{c}{ Tinggi Tanaman 2 MST } \\
$\mathrm{A}_{0}$ & 25,56 & 29,33 & 25,39 & 25,72 & 26,50 \\
$\mathrm{~A}_{1}$ & 30,06 & 23,95 & 28,67 & 29,78 & 28,11 \\
\hline Rataan & 27,81 & 26,64 & 27,03 & 27,75 \\
\hline \multicolumn{5}{c}{ Tinggi Tanaman 4 MST } \\
$\mathrm{A}_{0}$ & 70,61 & 71,67 & 71,39 & 65,50 & $69,79 \mathrm{~b}$ \\
$\mathrm{~A}_{1}$ & 83,39 & 74,83 & 79,61 & 77,72 & $78,89 \mathrm{a}$ \\
\hline Rataan & 77,00 & 73,25 & 75,50 & 71,61 \\
\hline \multicolumn{7}{c}{ Tinggi Tanaman 6 MST } \\
$\mathrm{A}_{0}$ & 135,00 & 139,50 & 139,50 & 138,39 & $138,10 \mathrm{a}$ \\
$\mathrm{A}_{1}$ & 164,56 & 147,95 & 154,50 & 146,17 & $153,29 \mathrm{~b}$ \\
\hline Rataan & 149,78 & 143,72 & 147,00 & 142,28 \\
\hline Keterangan: angka yang diikuti oleh huruf yang sama pada baris \\
dan kolom yang sama menujukkan berbeda tidak \\
nyata pada BNJ taraf 5\%.
\end{tabular}

\section{Luas Daun $\left(\mathrm{cm}^{2}\right)$}

Hasil analisis pengamatan dan analisis sidik ragam dapat dilihat luas daun tanaman jagung manis pada interaksi pupuk kandang ayam dengan pupuk kalium pada umur 2, 4, dan 6 MST dapat dilihat pada Tabel 8.

Tabel 8. Luas daun tanaman jagung manis pada interaksi pupuk kandang ayam dengan pupuk kalium pada umur 2, 4, dan 6 MST

\begin{tabular}{cccccc}
\hline Perlakuan & $\mathrm{K}_{0}$ & $\mathrm{~K}_{1}$ & $\mathrm{~K}_{2}$ & $\mathrm{~K}_{3}$ & Rataan \\
\hline \multicolumn{5}{c}{ Luas Daun 2 MST } \\
$\mathrm{A}_{0}$ & 29,54 & 33,58 & 30,08 & 29,67 & 30,72 \\
$\mathrm{~A}_{1}$ & 33,92 & 26,25 & 32,33 & 33,50 & 31,50 \\
\hline Rataan & 31,73 & 29,92 & 31,21 & 31,58 \\
\hline \multicolumn{5}{c}{ Luas Daun 4 MST } \\
$\mathrm{A}_{0}$ & 176,96 & 179,50 & 172,25 & 162,38 & 172,77 \\
$\mathrm{~A}_{1}$ & 232,42 & 192,46 & 207,75 & 158,46 & 197,77 \\
\hline Rataan & 204,69 & 185,98 & 190,00 & 160,42 \\
\hline \multicolumn{5}{c}{ Luas Daun 6 MST } \\
$\mathrm{A}_{0}$ & 417,08 & 384,08 & 410,96 & 421,25 & 408,34 \\
$\mathrm{~A}_{1}$ & 553,08 & 427,04 & 487,46 & 362,79 & 457,59 \\
\hline Rataan & 485,08 & 405,56 & 449,21 & 392,02 \\
\hline Keterangan: angka yang diikuti oleh huruf yang sama pada baris \\
\multicolumn{6}{c}{ dan kolom yang sama menujukkan berbeda tidak } \\
nyata pada BNJ taraf 5\%.
\end{tabular}

Pada Tabel 8 terlihat bahwa pemberian pupuk kandang (A), pupuk kalium (K) dan interaksinya berpengaruh tidak nyata terhadap luas daun tanaman jagung manis pada pengamatan umur 2, 4 dan 6 MST. Luas daun umur 2 MST dengan rataan tertinggi pada A1K0 yaitu $33,92 \mathrm{~cm}^{2}$. Pengamatan luas daun umur 4 MST dengan rataan tertinggi pada A1K0 yaitu 232,42 $\mathrm{cm}^{2}$. Pengamatan luas daun umur 6 MST dengan rataaan tertinggi pada A1K0 yaitu 553,08 $\mathrm{cm}^{2}$.

\section{Bobot Kering (Tajuk, Akar, dan Total)}

Hasil analisis pengamatan dan analisis sidik ragam dapat dilihat bahwa bobot kering tajuk, akar, dan total tanaman jagung manis pada interaksi pupuk kandang ayam dan pupuk kalium dapat dilihat pada Tabel 9.

Pemberian pupuk kandang ayam berpengaruh nyata terhadap bobot kering tajuk, bobot kering akar, dan 
bobot kering total tanaman jagung manis. Pemberian pupuk kalium berpengaruh nyata terhadap bobot kering tajuk dan bobot kering total tanaman jagung manis.

Tabel 9. Bobot kering tajuk dan akar tanaman jagung manis pada interaksi pupuk kandang ayam dengan pupuk kalium

\begin{tabular}{cccccc}
\hline Perlakuan & $\mathrm{K}_{0}$ & $\mathrm{~K}_{1}$ & $\mathrm{~K}_{2}$ & $\mathrm{~K}_{3}$ & Rataan \\
\hline \multicolumn{5}{c}{ Bobot Kering Tajuk $(\mathrm{g})$} \\
$\mathrm{A}_{0}$ & 43,86 & 41,15 & 58,24 & 48,78 & $48,01 \mathrm{~b}$ \\
$\mathrm{~A}_{1}$ & 70,29 & 50,46 & 64,52 & 75,87 & $65,28 \mathrm{a}$ \\
\hline Rataan & $57,07 \mathrm{a}$ & $45,80 \mathrm{~b}$ & $61,38 \mathrm{a}$ & $62,32 \mathrm{a}$ \\
\hline \multicolumn{5}{c}{ Bobot Kering Akar $(\mathrm{g})$} \\
$\mathrm{A}_{0}$ & 11,40 & 11,25 & 16,40 & 12,48 & $12,88 \mathrm{~b}$ \\
$\mathrm{~A}_{1}$ & 19,21 & 15,73 & 16,51 & 16,75 & $17,05 \mathrm{a}$ \\
\hline Rataan & 15,30 & 13,49 & 16,46 & 14,62 \\
\hline \multicolumn{5}{c}{ Bobot Kering Total (g) } \\
$\mathrm{A}_{0}$ & 55,26 & 52,41 & 74,64 & 61,26 & $60,89 \mathrm{~b}$ \\
$\mathrm{~A}_{1}$ & 89,49 & 66,18 & 81,03 & 92,62 & $82,33 \mathrm{a}$ \\
\hline Rataan & $72,37 \mathrm{a}$ & $59,29 \mathrm{~b}$ & $77,84 \mathrm{a}$ & $76,94 \mathrm{a}$ \\
\hline Keterangan: angka yang diikuti oleh huruf yang sama pada & baris dan kolom yang sama menujukkan berbeda \\
& tidak nyata pada BNJ taraf 5\%
\end{tabular}

Tabel 9 dapat dilihat bahwa interaksi perlakuan pupuk kandang ayam dan pemberian pupuk kalium pada luas daun tanaman jagung manis terlihat pada rataan perlakuan A1K3 dengan nilai tertinggi 75,87 g. Interaksi perlakuan pupuk kandang ayam dan pemberian pupuk kalium pada luas daun tanaman jagung manis terlihat pada rataan perlakuan A1K0 dengan nilai tertinggi 19,21 g. Interaksi perlakuan pupuk kandang ayam dan pemberian pupuk kalium pada bobot kering tanaman jagung manis terlihat pada rataan perlakuan A1K3 dengan nilai tertinggi 92,62 $\mathrm{g}$.

\section{Kandungan K dan Mg pada Daun}

Hasil analisis pengamatan dan analisis sidik ragam dapat dilihat bahwa kandungan $\mathrm{K}$ dan $\mathrm{Mg}$ di daun tanaman jagung manis pada interaksi pupuk kandang ayam dan pupuk kalium dapat dilihat pada Tabel 10 .

Tabel 10. Kandungan $\mathrm{K}$ dan $\mathrm{Mg}$ di daun tanaman jagung manis pada interaksi pupuk kandang ayam dengan pupuk kalium

\begin{tabular}{cccccc}
\hline Perlakuan & $\mathrm{K}_{0}$ & $\mathrm{~K}_{1}$ & $\mathrm{~K}_{2}$ & $\mathrm{~K}_{3}$ & Rataan \\
\hline \multicolumn{5}{c}{ Kandungan $\mathrm{K}(\%)$} \\
$\mathrm{A}_{0}$ & 1,17 & 1,26 & 1,35 & 1,57 & $1,34 \mathrm{~b}$ \\
$\mathrm{~A}_{1}$ & 1,56 & 1,51 & 1,50 & 1,71 & $1,57 \mathrm{a}$ \\
\hline Rataan & $1,37 \mathrm{~b}$ & $1,39 \mathrm{~b}$ & $1,43 \mathrm{~b}$ & $1,64 \mathrm{a}$ \\
\hline \multicolumn{5}{c}{ Kandungan $\mathrm{Mg} \mathrm{( \% )}$} \\
$\mathrm{A}_{0}$ & 0,29 & 0,30 & 0,36 & 0,35 & $0,32 \mathrm{~b}$ \\
$\mathrm{~A}_{1}$ & 0,35 & 0,37 & 0,38 & 0,43 & $0,38 \mathrm{a}$ \\
\hline Rataan & 0,32 & 0,34 & 0,37 & 0,39 \\
\hline
\end{tabular}

Keterangan: angka yang diikuti oleh huruf yang sama pada baris dan kolom yang sama menujukkan berbeda tidak nyata pada BNJ taraf 5\%

Tabel 10 dapat dilihat bahwa pemberian pupuk kandang ayam berpengaruh nyata terhadap kandungan $\mathrm{K}$ dan $\mathrm{Mg}$ di daun tanaman jagung manis. Pemberian pupuk kalium berpengaruh nyata terhadap kandungan $\mathrm{K}$ di daun tanaman jagung manis. Interaksi perlakuan pupuk kandang ayam dan pemberian pupuk kalium terhadap kandungan kalium pada daun jagung manis terlihat pada rataan perlakuan A1K3 dengan nilai tertinggi $1,71 \%$. interaksi perlakuan pupuk kandang ayam dan pemberian pupuk kalium terhadap kandungan magnesium pada daun jagung manis terlihat pada rataan perlakuan A1K3 dengan nilai tertinggi $0,43 \%$.

\section{Serapan Hara K dan Mg}

Hasil analisis pengamatan dan analisis sidik ragam dapat dilihat bahwa serapan hara $\mathrm{K}$ dan $\mathrm{Mg}$ tanaman jagung manis pada interaksi pupuk kandang ayam dan pupuk kalium dapat dilihat pada Tabel 11 .

Tabel 11. Serapan hara K dan Mg tanaman jagung manis pada interaksi pupuk kandang ayam dengan pupuk kalium

\begin{tabular}{cccccc}
\hline Perlakuan & $\mathrm{K}_{0}$ & $\mathrm{~K}_{1}$ & $\mathrm{~K}_{2}$ & $\mathrm{~K}_{3}$ & Rataan \\
\hline \multicolumn{5}{c}{ Serapan Hara $\mathrm{K}(\%)$} \\
$\mathrm{A}_{0}$ & 0,63 & 0,64 & 0,97 & 0,89 & $0,78 \mathrm{~b}$ \\
$\mathrm{~A}_{1}$ & 1,36 & 0,93 & 1,20 & 1,51 & $1,25 \mathrm{a}$ \\
\hline Rataan & 1,00 & 0,78 & 1,08 & 1,20 \\
\hline \multicolumn{5}{c}{ Serapan Hara Mg $(\%)$} \\
$\mathrm{A}_{0}$ & 0,16 & 0,15 & 0,26 & 0,20 & $0,19 \mathrm{~b}$ \\
$\mathrm{~A}_{1}$ & 0,31 & 0,22 & 0,30 & 0,37 & $0,30 \mathrm{a}$ \\
\hline Rataan & 0,23 & 0,18 & 0,28 & 0,28 \\
\hline
\end{tabular}

Keterangan: angka yang diikuti oleh huruf yang sama pada baris dan kolom yang sama menujukkan berbeda tidak nyata pada $\mathrm{BNJ}$ taraf $5 \%$

Tabel 11 dapat dilihat bahwa pemberian pupuk kandang ayam berpengaruh nyata terhadap serapan hara $\mathrm{K}$ dan $\mathrm{Mg}$ pada tanaman jagung manis, namun pemberian pupuk kalium dan interaksinya berpengaruh tidak nyata. Interaksi perlakuan pupuk kandang ayam dan pemberian pupuk kalium terhadap serapan hara kalium pada tanaman jagung manis terlihat pada rataan perlakuan A1K3 dengan nilai tertinggi $1,51 \%$. Interaksi perlakuan pupuk kandang ayam dan pemberian pupuk kalium terhadap serapan hara magnesium pada tanaman jagung manis terlihat pada rataan perlakuan A1K3 dengan nilai tertinggi 0,37\%.

\section{Pengaruh Interaksi Pupuk Kandang Ayam dengan Pupuk Magnesium}

Pada perlakuan penggunaan pupuk kandang ayam, seluruh peubah amatan yaitu tinggi tanaman umur 4 MST dan 6 MST, bobot kering tajuk, bobot kering akar, bobot kering tanaman, kandungan $\mathrm{K}$ daun, kandungan $\mathrm{Mg}$ daun, serapan hara $\mathrm{K}$ dan serapan hara $\mathrm{Mg}$ berpengaruh nyata dibandingkan dengan tanpa penggunaan pupuk kandang ayam. Hal ini dapat terjadi karena pupuk kandang ayam merupakan pupuk organik yang mampu meningkatkan bahan organik, memperbaiki struktur tanah, meningkatkan kemampuan tanah menyimpan air, meningkatkan aktifitas biologi tanah, meningkatkan kapasistas tukar kation (KTK), mengurangi fiksasi fosfat oleh $\mathrm{Al}$ dan Fe pada tanah masam dan meningkatkan kadar hara tanah. Sesuai dengan Stevenson dalam Thamrin, (2000) menyatakan bahwa bahan organik merupakan sumber cadangan unsur hara $\mathrm{N}, \mathrm{P}, \mathrm{K}$ dan $\mathrm{S}$ serta unsur hara mikro (Fe, Cu, Mn, Zn, B, Mo, Ca) akan dilepaskan secara berlahan-lahan melalui proses dekomposisi dan mineralisasi untuk mendukung 
pertumbuhan tanaman. Senyawa $N$ yang terkandung dalam bahan organik berperan dalam sintesa asam amino dan protein secara optimal, selanjutnya digunakan dalam proses pertumbuhan dan perkembangan tanaman.

Pada perlakuan pemberian magnesium, peubah amatan yang nyata berpengaruh adalah bobot kering tajuk, bobot kering akar, bobot kering tanaman, dan kandungan $\mathrm{Mg}$ daun dibandingkan dengan tanpa penggunaan dolomit. Dari peubah amatan yang berpengaruh nyata, diperoleh bobot kering tajuk, bobot kering akar dan bobot kering tanaman lebih tinggi bobotnya pada perlakuan tanpa dolomit. Hal ini terjadi karena kandungan $\mathrm{Mg}$ tanah pada awal penelitian bernilai $0,72 \mathrm{me} / 100 \mathrm{~g}$ tanah dan menurut kriteria penilaian sifat kimia tanah dari staf pusat penelitian kelapa sawit (1990) adalah berkreteria agak tinggi yang berarti bahwa tanpa diberikan pupuk Mg (dolomit), serapan tanaman berjalan efektif sehingga meningkatkan hara $\mathrm{Mg}$ pada daun.

Magnesium ( $\mathrm{Mg}$ ) merupakan bahan penting dalam tanah air tanah, air danau dan sungai. Magnesium dapat meningkatkan $\mathrm{pH}$ dan mempunyai pengaruh yang menguntungkan dalam pengembangan struktur tanah. Magnesium juga merupakan unsur hara makro esensial dalam pertumbuhan tanaman (Tan, 1996). Menurut Marschner, (1995) fungsi Mg terutama adalah dalam pembentukan dinding sel dan dalam mempertahankan keutuhan membran yang membatasi sitoplasma, vakuola dan inti sel. Magnesium berperan dalam pemanjangan sel dan pembentukan protein dalam mitokondria. Selain itu magnesium dalam tanaman berfungsi untuk menaikkan kecepatan dan pembentukan akar, memperbaiki vigor tanaman, berpengaruh terhadap serangan hara lainnya, menetralkan keracunan pada tanaman, serta mendorong produksi biji dan benih (Leiwakabessy, 1998).

Interaksi antara pupuk kandang ayam dan dolomit berpengaruh tidak nyata pada seluruh peubah amatan. Hal ini dapat terjadi karena perlakuan yang diberikan belum mampu mempengaruhi ketersediaan maupun penyerapan hara secara maksimal. Adapun hal lainnya yang menyebabkan tidak adanya pengaruh yang nyata terhadap seluruh peubah amatan diduga interaksi antara kedua perlakuan kurang mendukung satu sama lain sehingga efeknya pertumbuhan tanaman tidak merespon dan ini sesuai dengan pendapat Munawar, (2011) menyatakan bahwa pertumbuhan tanaman yang baik dapat tercapai bila faktor yang mempengaruhi pertumbuhan berimbang dan menguntungkan.

\section{Pengaruh Interaksi Pupuk Kandang Ayam dengan Pupuk Kalium}

Pada perlakuan penggunaan pupuk kandang ayam, seluruh peubah amatan yaitu tinggi tanaman umur 4 MST dan 6 MST, bobot kering tajuk, bobot kering akar, bobot kering tanaman, kandungan $\mathrm{K}$ daun, kandungan $\mathrm{Mg}$ daun, serapan hara $\mathrm{K}$ dan serapan hara $\mathrm{Mg}$ berpengaruh nyata dibandingkan dengan tanpa penggunaan pupuk kandang ayam. Pada perlakuan penggunaan pupuk kalium berpengaruh nyata terhadap peubah amatan bobot kering tajuk, bobot kering tanaman, kandungan kalium pada daun, kandungan magnesium pada daun, dan serapan hara magnesium.
Hal ini dapat terjadi karena pupuk kalium yang diberikan merangsang penyerapan kalium tanah dari pada hanya hara kalium yang sudah ada di tanah. Hal ini dapat terjadi karena salah satu fungsi kalium adalah meningkatkan transportasi hasil fotosintesis dari daun ke seluruh jaringan tanaman yang membutuhkan. Tanpa adanya unsur kalium yang cukup, sistem transportasi ini akan rusak.

Hal ini sesuai dengan Krenatita, (2004) unsur kalium (K) juga sangat berperan dalam pertumbuhan tanaman misalnya untuk memacu translokasi karbohidrat dari daun ke organ tanaman. Mengel \& Haeder dalam Mas'ud, (1992) menyatakan bahwa translokasi fotosintat ke buah tanaman tomat nyata dipengaruhi oleh hara kalium. Kalium nyata mempertinggi pergerakan fotosintesis keluar dari daun menuju akar dan akan meningkatkan penyediaan energi untuk pertumbuhan akar dan untuk perkembangan ukuran serta kualitas buah.

Interaksi antara pupuk kandang ayam dan pupuk kalium berpengaruh nyata pada tinggi tanaman umur 2 MST. Hasil tertinggi didapat pada perlakuan A1K0 dengan dosis pupuk kandang ayam 100 gr/polibeg dan tanpa pupuk kalium. Hal ini dapat terjadi karena pada masa awal vegetatif tanaman jagung manis pertumbuhan tanaman lebih dipengaruhi oleh bahan organik yang menyediakan unsur hara yang dibutuhkan tanaman serta mempengaruhi keadaan tanah sehingga unsur hara lebih mudah diserap oleh tanaman. Hal ini sesuai dengan Harsono, (2009) bahwa pupuk kandang ayam dapat menyumbangkan unsur hara yang diperlukan tanaman, seperti N, P, K, dan beberapa unsur hara mikro berupa Fe, $\mathrm{Zn}$, dan Mo. Secara umum perlakuan pupuk kandang ayam sebanyak 10 ton/ha mampu meningkatkan pertumbuhan vegetatif dan generatif tanaman yang dibudidayakan dikarnakan kandungan unsur hara nitrogen yang ada di dalam pupuk kandang ayam bermanfaat untuk merangsang pertumbuhan tanaman, khususnya batang dan daun (Melati, 2005).

\section{Pengaruh Interaksi Pupuk Magnesium dengan Kalium}

Pada interaksi perlakuan pemberian magnesium dan pupuk kalium berpengaruh nyata terhadap peubah amatan bobot kering tajuk, bobot kering tanaman. Adapun hasil analisis pemberian magnesium dan pupuk kalium secara tunggal juga berpengaruh nyata terhadap bobot kering tajuk dan bobot kering tanaman. Pada hasil analisis interaksi keduanya juga mempunyai pengaruh nyata, hal ini dapat terjadi karena dolomit merupakan pupuk yang berasal dari endapan mineral sekunder yang banyak mengandung unsur $\mathrm{Ca}$ dan $\mathrm{Mg}$ dengan rumus kimia $\mathrm{CaMg}$ (CO3)2. Pupuk dolomit di samping menambah $\mathrm{Ca}$ dan $\mathrm{Mg}$ dalam tanah juga memperbaiki keasaman tanah serta meningkatkan ketersediaan unsur yang lain misalnya $\mathrm{N}$ dan P ( Wibowo, 1983).

Berdasarkan hasil penelitian Sanjaya, (2002) Aplikasi kalium pada jagung manis dapat meningkatkan bobot tongkol yang dihasilkan dan meningkatkan rasa kemanisannya. Didalam tubuh tanaman, unsur kalium berfungsi dalam proses pembentukan gula dan pati, translokasi gula, aktifitas enzim dan pergerakan stomata.

Peningkatan bobot dan kandungan gula pada 
tongkol dapat terjadi dengan cara mengefisiensi proses fotosintesis pada tanaman dan meningkatkan translokasi fotosintat ke bagian tongkol. Laju pertumbuhan tongkol sebagai dasar kekuatan organ pengguna dan penampung hasil fotosintat sangat ditentukan oleh kalium. Disamping itu kalium juga dapat mencegah transportasi gula yang tidak normal dari daun ke biji. Selain itu unsur kalium juga mempunyai peranan dalam mengatur tata air didalam sel dan transfer kation melewati membran.

Magnesium yang ada pada dolomit dapat memberikan peranan sebagai aktivator dalam transportasi energi beberapa enzim di dalam tanaman . Sesuai dengan Poerwodido (1993), peranan yang dimiliki magnesium berupa, sebagai bagian essensial klorofil yang memberikan warna hijau pada daun, komponen dalam proses pembentukan gula dari karbon dioksida (CO2) dan air (H2O) saat penyinaraan oleh matahari, sebagai unsur pengatur penyerapan unsur hara lainnya dari dalam tanah, bertindak sebagai alat transportasi phosfor didalam tubuh tanaman, sebagai pendorong pembentukan minyak dan lemak, dan sebagai pemindah zat pati (karbohidrat) didalam tanaman.

\section{Pengaruh Interaksi Pupuk Kandang Ayam, Magnesium dan Kalium}

Interaksi pupuk kandang ayam, dolomit dan pupuk kalium berpengaruh nyata terhadap bobot kering akar. Hal ini dikarenakan pengaruh yang besar dari magnesium yang terkandung dalam dolomit.

Magnesium termasuk unsur hara yang esensial yang diserap tanaman dalam bentuk $\mathrm{Mg}^{2+}$. Menurut Taufiq, (2009) magnesium dalam tanah dapat meningkatkan penyerapan zat zat hara yang sudah ada dalam tanah yang berasal dari bahan organik maupun dari pupuk yang ditambahkan, menjaga tingkat ketersediaan unsur hara mikro sesuai kebutuhan tanaman, memperbaiki porositas tanah, struktur serta aerasi tanah sekaligus bermanfaat bagi mikrobiologi dan kimiawi tanah sehingga tanah menjadi gembur, sirkulasi udara menjadi lancar dan menjadikan akar bebas bergerak menghisap unsur hara dari tanah.

Penggunaan pupuk kandang ayam juga mempengaruhi pertumbuhan tanaman jagung melalui pengaruh nyata bobot kering akar, sesuai dengan pendapat Wulandari, (2011) yang menyatakan bahwa untuk meningkatkan pertumbuhan dan hasil dari tanaman kacang tanah, karena kandungan senyawa N, P dan $\mathrm{K}$ yang sangat tinggi pada pupuk kandang ayam. Karena jumlah bobot hara yang terdapat pada pupuk kandang ayam lebih tinggi dibandingkan dari pupuk kandang yang lain.

Begitu juga dengan pendapat Ispandi \& Munip, (2009) mengatakan efektivitas pupuk Kalium diperlukan pada kacang tanah karena unsur K sangat penting dalam proses pembentukan biji kacang tanah bersama hara $\mathrm{P}$ disamping juga penting sebagai pengatur berbagai mekanisme dalam proses metabolik seperti fotosintesis, transportasi hara dari akar ke daun, translokasi asimilat dari daun ke seluruh jaringan tanaman. Sedangkan pupuk kandang kotoran ayam akan sangat efektif untuk meningkatkan pertumbuhan dan hasil dari tanaman kacang tanah, karena kandungan senyawa $\mathrm{N}, \mathrm{P}$ dan $\mathrm{K}$ yang sangat tinggi pada pupuk kandang ayam.

\section{KESIMPULAN}

Pemberian pupuk kalium yang di aplikasi pupuk kandang ayam berpengaruh nyata terhadap tinggi tanaman umur 2 MST dengan perlakuan A1K0 dengan nilai tertinggi 30,06 $\mathrm{cm}$. Pemberian pupuk magnesium yang di aplikasi pupuk kandang ayam berpengaruh tidak nyata terhadap semua peubah amatan. Interaksi antara pemberian pupuk kalium dan pupuk magnesium yang di aplikasi pupuk kandang ayam berpengaruh nyata terhadap bobot kering akar dengan perlakuan A1D0K1 dengan nilai tertinggi $20,93 \mathrm{~g}$.

\section{DAFTAR PUSTAKA}

Admaja, G. 2006. Evaluasi adaptabilitas tiga genotipe jagung manis di dua lokasi dataran rendah. Skripsi. Fakultas Pertanian Institut Pertanian Bogor.

Agus. 2012. Luas daun jagung dengan metode konstanta. Agussupriana.blogspot.com. Diakses pada tanggal 03 November 2016.

Alfon dan Aryantoro. 1993. Studi pemupukan kalium terhadap pertumbuhan dan hasil jagung manis (Zea mays saccharata Struth) varietas Super Bee. ISSN : 1979-6870.

Anonimus. 2002. Sweet Corn Baby Corn. Penebar Swadaya, Jakarta.

Anonimus. 1992. Teknik Bercocok Tanam Jagung. Kanisius. Yogyakarta. $140 \mathrm{hlm}$.

Badan Pusat Statistik [BPS]. 2016. Sumatera Utara Dalam Angka. Badan Pusat Statistik Provinsi Sumatera Utara. Sumatera Utara. Diakses pada hari selasa tanggal 29 Maret 2017.

Burhanuddin. 2009. Penampilan beberapa varietas/galur jagung terhadap penyakit bulai. Prosiding Seminar Ilmiah dan Pertemuan Tahunan PEI dan PFI XX Komisariat Daerah Sulawesi Selatan.

Damanik, M.M.B., dkk. 2011. Kesuburan tanah dan pemupukan. USU Press. Medan

Dobermann. A and T.H. Fairhurst. 2000. Rice: Nutrient Disorders \& Nutrient Management. International Rice Research Institute and Potash \& Phosphate Institute/Potash \& Phosphate Institute of Canada.

Emedinta, Ardyan. 2004. Pengaruh taraf pupuk organik yang diperkaya terhadap pertumbuhan jagung manis dan sifat kimia tanah pada latosol di Darmaga. Skripsi. Fakultas Pertanian Institut Pertanian Bogor.

Farnham, D.E., Benson, G.O., Pearce, R.B.(2003). Corn perspective and culture. Chapter 1. In: PJ White, LA Johnson, eds. Corn: chemistry and technology, Edition 2nd. American Association of Cerial Chemicals, Inc. St. Paul, Minesota, USA. pp 1-33.

Forth, H. D. 1978. Dasar-dasar ilmu tanah. Diterjemahkan oleh Soenartono Adisoemarto, Gadjah Mada University Press, Yogyakarta

Gomez K. A dan Gomez, A. A. 2007. Prosedur statistik untuk penelitian pertanian. Edisi Kedua. UI Press. Jakarta

Hardjowigeno, S. 2007. Ilmu tanah. Akademika Pressindo. Jakarta 
Haris, Adri, S., dan Krestiani, V. 2005. Studi Pemupukan Kalium Terhadap Pertumbuhan Dan Hasil Jagung Manis (Zea mays saccharata Sturt) Varietas Super Bee .Universitas Sumatera Utara.

Harsono, Aryanto 2009 Pupuk organik tanpa nama jurnal vol 1 no I (http://isroi.wordpress.com) Diakses pada hari selasa tanggal 03 Mei 2016.

Hartatik, dkk. 2004. Uji mutu dan efektivitas pupuk alternatif anorganik balai penelitian tanah. Pusat Penelitian dan Pengembangan Tanah dan Agroklimat.Badan Penelitian dan Pengembangan Pertanian. Departemen Pertanian. Jakarta

Hartatik, W., D. Setyorini, L.R. Widowati, dan S. Widati. 2005. Laporan Ahir Penelitian Teknologi pengelolaan Hara Pada Budidaya Pertanian Organik. Laporan Bagian Proyek Penelitian Sumberdaya Tanah dan Proyek Pengkajian Teknologi Pertanian Partisipatif.

Havlin, J. L., J. D. Beaton, S. L. Tisdale and W. L. Nelson. 1999. Soil Fertility and Fertilizers An Introduction to Nutrient Management. 6th ed. Prentice Hall, Upper Saddle River, New Jersey.pp. 497. Nelson, L.A. and R.L. Anderson.1977.Http://varitasnet/varitas10/varimage /jagungmanisbonanza/01.12.2014.pdf

Irfan, M. 1999. Respon Tanaman Jagung (Zea mays L.) Terhadap Pengelolaan Tanah dan Kerapatan Tanam pada Tanah Andisol dan Ultisol. Pasca Sarjana Universitas Sumatera Utara.

Iskandar S., 2003. Zat-Zat Berbahaya dalam Produk Olahan. http://www.chem-is-try.org. Diakses pada hari selasa tanggal 03 Mei 2016.

Ispandi Anwar dan Munip Abdul. 2004. Efektivitas pupuk PK dan frekuensi pemberian pupuk K dalam meningkatkan serapan hara dan produksi kacang tanah di lahan kering alfisol. Jurnal. Ilmu Pertanian, 11(2), 11-24.

Kresnatita, S. 2004. Pengaruh pemberian pupuk organik dan nitrogen terhadap pertumbuhan dan hasil tanaman jagung manis. Unibraw malang. Eugenia Volume 18 No. 1 April 2012

Leiwakabessy, F. M. 1988. Kesuburan tanah. Jurusan Tanah. Fakultas Pertanian IPB. Bogor.

Marshner, H. 1995. Mineral nutrition of higher plants. Second Edition. Academic Press. London

Mas'ud, P. 1992. Telaah kesuburan tanah. Angkasa. Bandung.

Melati dan Andriyani., 2005. Pengaruh pupuk kandang ayam dan pupuk hijau Calapogiunium mucunoides terhadap pertumbuhan dan produksi kedelai panen muda yang dibudidayakan secara organik. http://Journal.ipb.ac.id/index.php/jai. (Diakses pada tanggal 3 April 2017)

Munawar, A. 2011. Kesuburan tanah dan nutrisi tanaman. IPB press. Bogor.

Poerwowidodo, 1992. Telaah kesuburan tanah, Penerbit Angkasa Persada Jl. Kronolodong No. 37, Cetakan keempat Bandung.

Poerwowidodo. 1992. Telaah kesuburan tanah. Angkasa. Bandung.

Pusat Penelitian Tanah dan Agroklimat. 2000. Sumber Daya Lahan Indonesia dan Pengelolaannya. Badan
Penelitian dan Pengembangan Pertanian Departemen Pertanian. Bogor

Rahman, Abdir. 2010. Pengaruh Pupuk Kandang Ayam Terhadap Hasil Pertumbuhan Tanaman Terung. Universitas Muara Bungo.

Rukmana, H. 1997. Usaha Tani Jagung. Yogyakarta: Kanisius.

Rukmana, R. 2010. Jagung Budidaya, pascapanen, Penganekaragaman Panagan. semarang. CV Aneka Ilmu.

Sanchez, P.A. 1976. Properties and Management of soils in The Tropics. Jhon Wiley \& Sons. New York.

Sanjaya, 2002. Interaksi Pemupukan Urea, TSP dan KCL Terhadap Pertumbuhan dan Produksi Jagung Manis.

Setyono, S. 1986. Kesuburan Tanah dan Nutrisi Tanaman. Pend. Pasca Sarjana. KPK UGM-UNIBRAW.

Soepardi, G. 1985. Menuju Pemupukan Berimbang Guna Meningkatkan Jumlah dan Mutu Hasil Pertanian. Dirjen Pertanian Tanaman Pangan. Jakarta. $63 \mathrm{hlm}$.

Steel, R. G. D. dan J. H. Torrie., 1993. Prinsip dan Prosedur Statistika (Pendekatan Biometrik) Penerjemah B. Sumantri. Gramedia Pustaka Utama, Jakarta.

Sutton, RF. 1969. Form and Development of Conifer Root Systems. Commonwealth Agriculutural Bureaux Tech 7 : 130p. England.

Tan, K.H. 1996. Soil Sampling Preparation and Analysis. Marcel Dekkar, Inc. New York.

Taufiq. 2009. Magnesium (Mg) dan Pengaruh Defesiensinya terhadap Tanaman. Thophick.blogspot.co.id. diakses tanggal 2 Februari 2017

Thamrin, 2000. Perbaikan Beberapa Sifat Fisik Tanah dengan Pemberian Pupuk Organik dan Pengaruhnya Terhadap Produksi Padi Gogo. http:// www . google.Com

Warisno. 1998. Budidaya Jagung Hibrida. Yogyakarta: Kanisius.

Wibowo, Z.S., 1983. Pengaruh Mg tanah dan pemupukan Mg terhadap pertumbuhan tanaman. Hasil Penelitian Pertanian Indonesia. Februari 1985. Vol. m. (Abstr).

Widodo. 2008. Pupuk organik dan pupuk hayati. Jawa Barat: Balai Besar Penelitian dan Pengembangan Sumberdaya Lahan Pertanian.

Wulandari, Vonny. 2011. Pengaruh pemberian beberapa dosis pupuk kandang ayam terhadap pertumbuhan dan hasil tanaman rosella (Hibiscus Sabdariffa L.) Di Tanah Ultisol. Skripsi. Fakultas Pertanian, Universitas Andalas Padang. Pdf.

Yulianti, D., 2010. Pengaruh hormon organik dan pupuk organik cair (POC) Super Nasa terhadap produksi tanaman jagung manis (Zea mays saccharata Sturt). http://penelitian-organik-penelitian.blogspot.com /2010/03/pengaruh-hormon-organik-danpupuk.html. Diakses pada hari selasa tanggal 03 Mei 2016 